\title{
Idiopathic Granulomatous Hypophysitis with Rapid Onset: A Case Report
}

\author{
Hyun Joo Park ${ }^{1}$, Sung Hye Park², Jung Hee Kim ${ }^{3,4}$, Yong Hwy Kim¹,3 \\ Departments of ${ }^{1}$ Neurosurgery, ${ }^{2}$ Pathology, Seoul National University College of Medicine, Seoul, Korea \\ ${ }^{3}$ Pituitary Center, Seoul National University College of Medicine, Seoul, Korea \\ ${ }^{4}$ Division of Endocrinology and Metabolism, Department of Internal Medicine, Seoul National University College of Medicine, Seoul, Korea
}

\author{
Received July 21, 2018 \\ Revised October 23, 2018 \\ Accepted November 8, 2018 \\ Correspondence \\ Yong Hwy Kim \\ Department of Neurosurgery, \\ Seoul National University Hospital, \\ 101 Daehak-ro, Jongno-gu, \\ Seoul 03080, Korea \\ Tel: +82-2-2072-4062 \\ Fax: +82-2-744-8459 \\ E-mail: kimyh96@snu.ac.kr
}

\begin{abstract}
Idiopathic granulomatous hypophysitis $(\mathrm{IGH})$, a rare disease, requires differentiation from more common mass lesions of the sella such as pituitary adenoma, craniopharyngioma, Rathke's cleft cyst, or pituitary tuberculoma. IGH usually presents with an insidious onset of visual defects and headaches. On the other hand, rapid onset of neurologic and visual symptoms in an IGH patient is exceptionally rare. Here, we present a biopsy-proven case of IGH with rapid onset and satisfactory outcome after high dose steroid treatment.
\end{abstract}

Key Words Pituitary gland; Hypophysitis; Glucocorticoids; Sella turcica; Endoscopy; Adult.

\section{INTRODUCTION}

Idiopathic granulomatous hypophysitis (IGH) is a chronic inflammatory lesion of the pituitary gland and the second most common type of hypophysitis. IGH may mimic a pituitary adenoma or craniopharyngioma on MRI and usually present with insidious onset of symptoms including headaches, visual impairment, hormonal deficiencies, and cranial nerve palsies. On the other hand, a rapid onset of neurologic and visual symptoms in an IGH patient is rare. We present the case of rapid onset IGH treated successfully with glucocorticoids.

\section{CASE REPORT}

This study was approved by the institutional review board of the author's institution and an informed consent was obtained.

A 41-year-old female presented with a sudden onset of bilateral temporal headaches, blurred vision and diplopia that

This is an Open Access article distributed under the terms of the Creative Commons Attribution Non-Commercial License (https://creativecommons.org/licenses/by-nc/4.0) which permits unrestricted non-commercial use, distribution, and reproduction in any medium, provided the original work is properly cited.

Copyright $\odot 2019$ The Korean Brain Tumor Society, The Korean Society for NeuroOncology, and The Korean Society for Pediatric Neuro-Oncology began four days previously. Neurologic exams revealed left abducens nerve palsy. On further inquiry, the patient recounted that she had mild headaches, occasional galactorrhea and irregular menstruations for the previous two months. An MRI scan of the sella revealed a $2.2 \times 1.7 \mathrm{~cm}$ sized gadolinium-enhancing sellar mass with an increase in the mass size and further thickening of the infundibulum compared to the previous MRI performed one month prior (Fig. 1A).

Laboratory evaluations showed an elevated serum prolactin level, measuring 2,217.4 pmol/L (normal range 165-1,010 $\mathrm{pmol} / \mathrm{L}$ ). Basal hormone studies revealed a low cortisol level of $44.14 \mathrm{nmol} / \mathrm{L}(140-690 \mathrm{nmol} / \mathrm{L})$, a low luteinizing hormone (LH) at $0.8 \mathrm{IU} / \mathrm{L}$ (1-104 IU/L), a normal follicle-stimulating hormone (FSH) level of $3.1 \mathrm{IU} / \mathrm{L}(1-100 \mathrm{IU} / \mathrm{L})$ and a low estradiol level of $18.36 \mathrm{pmol} / \mathrm{L}$ (110-1,470 pmol/L). Her serum prolactin level was elevated to $1,652.2 \mathrm{pmol} / \mathrm{L}$ (165$1,010 \mathrm{pmol} / \mathrm{L}$ ). Thyroid function tests showed normal T3, T4 and low thyroid-stimulating hormone (TSH) levels at 2.14 $\mathrm{nmol} / \mathrm{L}(0.92-2.76 \mathrm{nmol} / \mathrm{L}), 10.68 \mathrm{pmol} / \mathrm{L}(12-30 \mathrm{pmol} / \mathrm{L})$, and less than $0.05 \mathrm{mIU} / \mathrm{L}(0.4-5 \mathrm{mIU} / \mathrm{L})$, respectively. Insulin-like growth factor 1 (IGF-1) level was decreased to $14.54 \mathrm{nmol} / \mathrm{L}$ $(18-60 \mathrm{nmol} / \mathrm{L})$. Rapid adrenocorticotropic hormone (ACTH) test results revealed hypocortisolism, with a basal cortisol level of $35.86 \mathrm{nmol} / \mathrm{L}$, a 30 -minute cortisol level of $184.8 \mathrm{nmol} / \mathrm{L}$, 


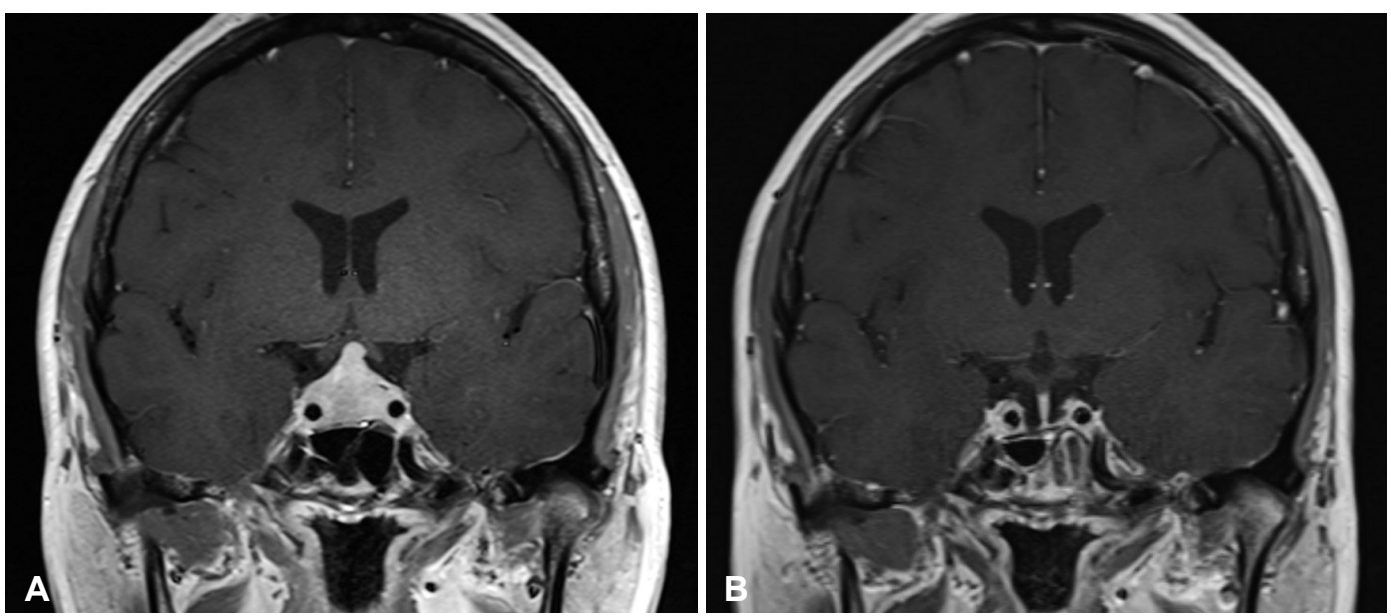

Fig. 1. MR at presentation (A) and post-operative 3 months (B). A: The lesion in the pituitary gland without the invasion of the bilateral cavernous sinus is moderately enhanced with gadolinium. The pituitary gland is not demarcated definitely, in contrast to the features of pituitary adenoma. The lesion is symmetric, encases both the left and the right internal carotid artery and compresses the optic chiasm. B: The thick pituitary stalk returned to the normal size and the pituitary gland has shrunken 3 months after steroid treatment. Note that the involvement of bilateral cavernous sinuses and mass effect on the optic chiasm has resolved.
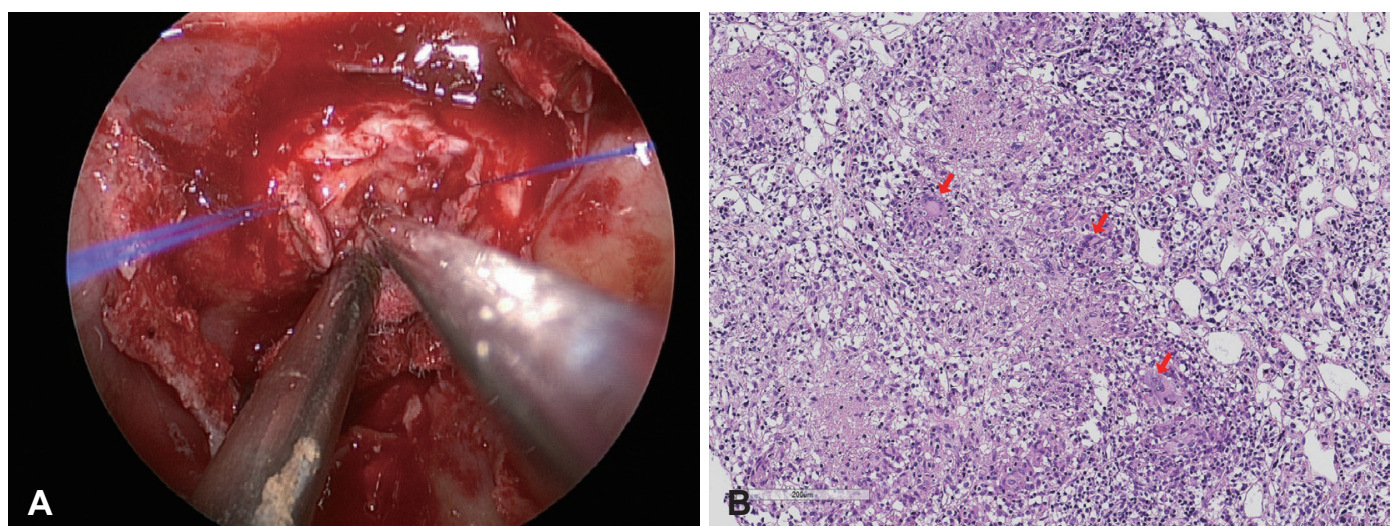

Fig. 2. Intraoperative (A) and pathologic (B) photographs. A: Gray lesion is exposed after dural incision. The pituitary gland surrounding the lesion lost its original yellow color and its consistency was mushy. B: Pituitary biopsy showing chronic granulomatous inflammation with central necrosis and giant cells (red arrows). There are atrophic pituitary lobules seen mainly in the right upper quadrant of this photo (hematoxylin-eosin staining, $\times 70$ ).

and a 60-minute cortisol level of $190.4 \mathrm{nmol} / \mathrm{L}$.

The patient then underwent an endoscopic transsphenoidal biopsy of the hypophysis (Fig. 2A). Permanent biopsy revealed chronic granulomatous inflammation with central caseous necrosis and multinucleated giant cells (Fig. 2B). An acid-fast staining (AFB) stain, mycobacterium tuberculosis nested polymerase chain reaction (PCR) and non-tuberculous mycobacteria-polymerase chain reaction (NTM-PCR) results were negative. IgG4 level was $8.5 \mathrm{mg} / \mathrm{dL}$, which was within normal range. Human chorionic gonadotropin and alpha-fetoprotein levels were assessed for the possibility of germ cell tumors, and were found to be within the normal range. Interestingly, the patient displayed an elevation of angiotensin-converting enzyme level at 1,375.03 nkat/L (normal <670 nkat/L), C-reactive protein level at $10.10 \mathrm{nmol} / \mathrm{L}$ (normal $0.76-28.5 \mathrm{nmol} / \mathrm{L}$ ) and lactate dehydrogenase level at $3.99 \mu \mathrm{kat} / \mathrm{L}$ (normal, 1.7-
$3.4 \mu \mathrm{kat} / \mathrm{L}$ ). Further rheumatologic evaluations for suspected giant cell arteritis due to the elevated ACE level yielded negative results. Serologic workups for syphilis, hepatitis B, hepatitis $\mathrm{C}$ or HIV were also negative. Repeat testing of IgG4 level was normal $(7.6 \mathrm{mg} / \mathrm{dL})$, and myeloperoxidase-targeting antineutrophil cytoplasmic antibodies and proteinase-3-targeting anti-neutrophile cytoplasmic antibody (ANCA) studies were all negative. The positron emission tomography-computed tomography for other malignancy displayed no hypermetabolic lesions except for the sellar lesion.

The patient recovered without any postoperative neurologic deficits. Postoperative diabetes insipidus was well controlled with intravenous administrations of desmopressin and later on, oral forms of desmopressin. She was given $15 \mathrm{mg}$ of oral prednisolone daily for 3 months, and then tapered to a $15 \mathrm{mg} /$ day of oral hydrocortisone. A postoperative MRI scan per- 
formed after three months revealed a markedly decreased residual pituitary gland with mildly thickened infundibulum (Fig. 1B).

\section{DISCUSSION}

Granulomatous hypophysitis is a rare pituitary disease, and it is the second most common type of hypophysitis following lymphocytic hypophysitis [1-4]. The incidence is estimated to be 1 case per 9 million people per year [5]. The prevalence of granulomatous hypophysitis is currently not precisely reported $[4,6]$. Granulomatous hypophysitis has a female preponderance, and is usually diagnosed in the fourth or fifth decade $[4,7]$.

Granulomatous hypophysitis is histologically differentiated from lymphocytic or xanthomatous hypohysitis by the presence of multinucleated giant cells with caseous necrosis [4]. Granulomatous hypophysitis can also occur as a secondary phenomenon due to other etiologies such as tuberculosis, sarcoidosis, syphilis, fungal infections, pituitary adenomas, Langerhans cell histiocytosis, Erdheim-Chester disease, Wegener's granulomatosis, and giant cell arteritis [2,8-11]. Therefore, IGH can be diagnosed after exclusion of other secondary causes.

The present case had typical demographic characteristics of
IGH. However, our patient complained of sudden severe headache, blurred vision, and diplopia. The most common presenting symptom in IGH is headache followed by menstrual changes, visual changes, and diabetes insipidus, but they are usually of insidious onset [4]. IGH cases with rapid onset symptoms have rarely been reported. Husain et al. [5] described a case of IGH manifesting as clinical pituitary apoplexy, and gross total resection improved the patient's visual symptoms postoperatively. The symptoms may be caused by hemorrhage or infarctions of the pituitary gland, which expands rapidly [4].

Imaging findings of IGH include a symmetric enlargement and homogeneous gadolinium enhancement of the pituitary gland, infundibular thickening, and normal sellar size $[2,4,12$, 13], and these were observed in our case as well. However, such findings may be seen in other diseases such as pituitary tuberculoma $[2,12,13]$. Sellar enhancement seen in tuberculoma differs from IGH in that it has central hypointensity with an irregularly enhancing rim, and additional tests such as an interferon gamma release assay test is needed for diagnosis $[1,14]$. Apart from aforementioned imaging findings, IGH can also appear as cystic lesions mimicking abscesses $[4,15,16]$. IgG4-related hypophysitis may also appear similar to IGH. The differential diagnosis should be made by a histological finding of sellar mass or extracranial diseases, high serum IgG4 levels,

Table 1. A summary of cases of idiopathic granulomatous hypophysitis in the literature

\begin{tabular}{|c|c|c|c|c|c|}
\hline Author (year) & Type of study & $\begin{array}{l}\text { Number } \\
\text { of cases }\end{array}$ & $\begin{array}{l}\text { Presenting } \\
\text { symptoms }\end{array}$ & Treatment & Outcome* \\
\hline \multirow[t]{3}{*}{$\begin{array}{l}\text { Hunn et al. } \\
\text { (2014) [4] }\end{array}$} & \multirow[t]{3}{*}{$\begin{array}{c}\text { Literature } \\
\text { review }\end{array}$} & \multirow[t]{3}{*}{82 cases } & \multirow{3}{*}{$\begin{array}{l}\text { Headache }(61 \%), \\
\text { visual change } \\
(40.2 \%)\end{array}$} & $\begin{array}{l}\text { 1. Excisional pituitary } \\
\text { surgery alone }\end{array}$ & 1. Resolved (90.5\%) \\
\hline & & & & $\begin{array}{l}\text { 2. Excisional surgery and } \\
\text { corticosteroids }\end{array}$ & 2. Resolved (68.4\%) \\
\hline & & & & $\begin{array}{l}\text { 3. Biopsy and } \\
\text { corticosteroids }\end{array}$ & 3. Resolved (87.5\%) \\
\hline $\begin{array}{l}\text { Husain et al. } \\
\text { (2014) [5] }\end{array}$ & Case report & $\begin{array}{l}1 \text { case (36-year-old } \\
\text { female) }\end{array}$ & Pituitary apoplexy & $\begin{array}{l}\text { Transsphenoidal removal } \\
\text { of the tumor for optic } \\
\text { nerve \& Lt cavernous } \\
\text { sinus decompression }\end{array}$ & $\begin{array}{l}\text { Improved } \\
\text { (postoperative } \\
\text { hypothyroidism) }\end{array}$ \\
\hline $\begin{array}{l}\text { Cavusoglu et al. } \\
\text { (2015) [16] }\end{array}$ & Case report & $\begin{array}{l}1 \text { case ( } 48 \text {-year-old } \\
\text { female) }\end{array}$ & Irregular menstruation & $\begin{array}{l}\text { Transsphenoidal surgical } \\
\text { excision }\end{array}$ & - \\
\hline $\begin{array}{l}\text { Kong et al. } \\
\text { (2015) [15] }\end{array}$ & Case report & $\begin{array}{l}1 \text { case (19-year-old } \\
\text { female) }\end{array}$ & $\begin{array}{l}\text { Severe bitemporal } \\
\text { headache }\end{array}$ & $\begin{array}{l}\text { Transsphenoidal surgical } \\
\text { excision, partial resection, } \\
\text { methylprednisolone }\end{array}$ & $\begin{array}{l}\text { Improved (visual } \\
\text { field deficits) }\end{array}$ \\
\hline $\begin{array}{c}\text { Wan Muhamad Hatta } \\
\text { et al. (2016) [19] }\end{array}$ & Case report & $\begin{array}{l}1 \text { case (39-year-old } \\
\text { female) }\end{array}$ & $\begin{array}{l}\text { Worsening of headaches } \\
\text { and blurring of vision }\end{array}$ & $\begin{array}{l}\text { Glucocorticoid+ } \\
\text { azathioprine }\end{array}$ & Resolved \\
\hline Ved et al. (2018) [21] & Case series & 6 cases & Visual deterioration & $\begin{array}{l}\text { Surgical excision } \\
\text { (TSA in } 5 / 6 \text {, craniotomy } \\
\text { in } 1 / 6)\end{array}$ & $\begin{array}{l}\text { Improved } \\
\text { (postoperative } \\
\text { hormonal deficiencies } \\
\text { in } 67 \% \text { of patients) }\end{array}$ \\
\hline
\end{tabular}

*Resolved, complete resolution of symptoms, no further neurologic deficits; Improved, alleviation of initial symptoms but remaining neurologic or hormonal deficiencies; Recurred, recurrence 
and clinical improvement with corticosteroid use. Thus, biopsy of the hypophysis is crucial in confirmation of diagnosis.

Treatment options of primary hypophysitis include the administration of corticosteroid, surgical excision, and radiosurgery $[17,18]$. The goal of treatment is to alleviate symptoms via hormone replacement and to decompress neurovascular structures [19]. Overall, the symptom resolution was achieved in $80 \%$ of IGH patients [4]. In a literature review of 82 cases, Hunn et al. [4] noted that the symptom resolution, hypopituitarism, and recurrence rate was not different between patients who had surgical excision and those who had a biopsy and steroid treatment. However, when patients were treated with surgical excision combined with steroid treatment, the outcome was poorer than when treated with surgical excision only. In addition, there was a case report of IGH unresponsive to prednisolone use [20]. A recent case series by Ved et al. [21] containing 6 patients with pituitary xanthogranuloma reported gross total resection in all patients, and no postoperative recurrence. However, intraoperative pituitary stalk injury led to permanent steroid replacement in $67 \%$ of patients, and rendered 4 out of 6 patients thyroxine-deficient [21]. On the other hands, recent case reports culminated in the alleviation of neurologic symptoms after corticosteroid use, and more studies favored corticosteroid treatment over excisional strategy alone (Table 1) $[18,19,22]$. Corticosteroid replacement in our patient unmasked diabetes insipidus and led to resolution of neurological symptoms.

IGH may be difficult to suspect from the initial presentation. As clinical or imaging diagnostic criteria may be ambiguous and overlap with other etiologies, histologic diagnosis is crucial in confirmation of diagnosis [23]. Establishment of diagnosis is the most important step in order to initiate corticosteroid therapy and prevent delays due to misdiagnosis as pituitary tumors or abscess. Prevention of unnecessary surgical intervention and possible postoperative morbidities may improve outcomes in patients with IGH.

In conclusion, glucocorticoid replacement may result in clinical resolution of IGH without the need for complete surgical resection. A biopsy of the lesion is required for diagnosis of this rare disease entity. Although the presentation of IGH is more common with an insidious onset of symptoms, patients can present with rapid onset of symptoms. Clinical resolution can be achieved by corticosteroid replacement. Thus, a heightened sense of suspicion for IGH is required in a patient presenting with a pituitary mass and rapid onset of neurologic symptoms to prevent unnecessary surgical intervention. Further research is required to elucidate the prevalence, prognostic and risk factors, diagnostic criteria, and optimal treatment options in IGH.

\section{Conflicts of Interest}

The authors have no potential conflicts of interest.

\section{Acknowledgments}

This research was funded by a grant (No.: NRF-2017R1A2B2008412) of the National Research Foundation funded by the Ministry of Science, ICT and Future Planning (MSIP) of Korea and a grant (No.: HI16C-1111-020016 to Kim YH) from the Korea Health Industry Development Institute (KHIDI), funded by the Ministry of Health \& Welfare, Republic of Korea.

\section{REFERENCES}

1. Srisukh S, Tanpaibule T, Kiertiburanakul S, et al. Pituitary tuberculoma: a consideration in the differential diagnosis in a patient manifesting with pituitary apoplexy-like syndrome. IDCases 2016;5:63-6.

2. Majumdar K, Barnard M, Ramachandra S, Berovic M, Powell M. Tuberculosis in the pituitary fossa: a common pathology in an uncommon site. Endocrinol Diabetes Metab Case Rep 2014;2014:140091.

3. Faje A. Hypophysitis: evaluation and management. Clin Diabetes Endocrinol 2016;2:15.

4. Hunn BH, Martin WG, Simpson S Jr, Mclean CA. Idiopathic granulomatous hypophysitis: a systematic review of 82 cases in the literature. Pituitary 2014;17:357-65.

5. Husain Q, Zouzias A, Kanumuri VV, Eloy JA, Liu JK. Idiopathic granulomatous hypophysitis presenting as pituitary apoplexy. J Clin Neurosci 2014;21:510-2.

6. Rickards AG, Barrett GM. Nontuberculous Addison's disease and its relationship to giant-cell granuloma and multiple glandular disease. Q J Med 1954;23:403-23.

7. Osawa S, Ogawa Y, Watanabe M, Tominaga T. Hypophysitis presenting with atypical rapid deterioration: with special reference to immunoglobulin G4-related disease-case report. Neurol Med Chir (Tokyo) 2009;49:622-5.

8. Alam T, Thomas S. Diabetes insipidus secondary to sarcoidosis presenting with caseating granuloma. BMJ Case Rep 2011;2011:bcr0120113702.

9. Al-Haddad S, Fandino R, Scheithauer BW, Galvis L, Syro LV, Kovacs K. Necrotizing granulomatous hypophysitis presenting as a sellar mass. Endocr Pathol 2011;22:6-9.

10. Ben Abid F, Abukhattab M, Karim H, Agab M, Al-Bozom I, Ibrahim WH. Primary pituitary tuberculosis revisited. Am J Case Rep 2017; 18:391-4.

11. Antony G, Dasgupta R, Chacko G, Thomas N. Pituitary tuberculoma with subsequent drug-resistant tuberculous lymphadenopathy: an uncommon presentation of a common disease. BMJ Case Rep 2017;2017: bcr2016218330.

12. Shukla S, Trivedi A, Singh K, Sharma V. Pituitary tuberculoma. J Neurosci Rural Pract 2010;1:30-1.

13. Tanimoto K, Imbe A, Shishikura K, et al. Reversible hypopituitarism with pituitary tuberculoma. Intern Med 2015;54:1247-51.

14. Saito K, Toda M, Shido S, Tomita T, Ogawa K, Yoshida K. Isolated pituitary tuberculoma. NMC Case Rep J 2014;1:33-6.

15. Kong X, Wang R, Yang Y, et al. Idiopathic granulomatous hypophysitis mimicking pituitary abscess. Medicine (Baltimore) 2015;94:e1099.

16. Çavuşoğlu M, Elverici E, Duran S, Komut E, Güreșçi S, Sakman B. Idiopathic granulomatous hypophysitis: a rare cystic lesion of the pituitary. Intern Med 2015;54:1407-10.

17. Iseda I, Hida K, Tone A, et al. Prednisolone markedly reduced serum IgG4 levels along with the improvement of pituitary mass and anterior pituitary function in a patient with IgG4-related infundibulo-hypophysitis. Endocr J 2014;61:195-203.

18. Leung GK, Lopes MB, Thorner MO, Vance ML, Laws ER Jr. Primary hypophysitis: a single-center experience in 16 cases. J Neurosurg 2004; 101:262-71.

19. Wan Muhamad Hatta SF, Hamdan MF, Md Ali SA, Abdul Ghani R. 
Granulomatous hypophysitis: a case of severe headache. BMJ Case Rep 2016;2016:bcr2016216395.

20. Kristof RA, van Roost D, Schramm J, Wichers M. Primary granulomatous hypophysitis not responsive to pulsed high dose prednisolone therapy: case report. J Neurol Neurosurg Psychiatry 1998;64:693-4.

21. Ved R, Logier N, Leach P, Davies JS, Hayhurst C. Pituitary xanthogranulomas: clinical features, radiological appearances and post-oper- ative outcomes. Pituitary 2018;21:256-65.

22. Su SB, Zhang DJ, Yue SY, Zhang JN. Primary granulomatous hypophysitis: a case report and literature review. Endocr J 2011;58:467-73.

23. Scanarini M, d'Avella D, Rotilio A, Kitromilis N, Mingrino S. Giantcell granulomatous hypophysitis: a distinct clinicopathological entity. J Neurosurg 1989;71(5 Pt 1):681-6. 